\title{
Effects of exercise and diet-induced weight loss on markers of inflammation II: impact on microRNA 21 and microRNA 146a expression and their regulatory role
}

\author{
S Simbo ${ }^{1 *}$, A Roque-Andrade ${ }^{2}$, B Lockard ${ }^{1}$, C Baetge ${ }^{1}$, S Mertens-Talcott ${ }^{2}$, C Rasmussen ${ }^{1}$, R Kreider $^{1}$ \\ From International Society of Sports Nutrition: 10th Annual ISSN Conference and Expo \\ Colorado Springs, CO, USA. 14-15 June 2013
}

\section{Background}

Obesity has been associated with inflammation. However, the mechanisms are not well understood. The purpose of this study was to determine if exercise and diet-induced weight loss would affect markers of inflammation via the Phosphatase and Tensin homologue Deleted from Chromosome-10 (PTEN), TNF receptor-associated factor 6 (TRAF6), Phosphatidylinositol-3-kinase (PI3k), Protein Kinase B (AKT or PKB), Nuclear Factor kappa Beta (NF-kB) signaling pathway through the regulation of microRNA 21 and microRNA 146a expression.

\section{Methods}

Forty-five overweight and sedentary women $(48.16 \pm 10.5$ $\mathrm{yr}, 45.9 \pm 4.4 \%$ body fat, BMI $\left.35.6 \pm 5.6 \mathrm{~kg} / \mathrm{m}^{2}\right)$ were randomized into a control group $(\mathrm{C}, \mathrm{n}=18)$ or an exercise and diet-induced weight loss group (EX, $n=27)$. Participants followed an energy-restricted diet $(1,200 \mathrm{kcal} / \mathrm{d}$ for 1 week and 1,500 kcal/d for 11 weeks; $30 \% \mathrm{CHO}, 45 \% \mathrm{P}$, and $25 \% \mathrm{~F}$ ) while participating in a circuit resistancetraining $(3 \mathrm{~d} / \mathrm{wk})$ program. The resistance training program included 30 seconds of resistance exercise interspersed with 30 seconds of continuous movement (calisthenics). Whole blood samples were obtained at 0 and 12 wks and centrifuged immediately to obtain white blood cells buffy coat for mRNA isolation. The microRNA (21 and 146a) and mRNA of IL-6, TNF- $\alpha$, (PTEN, TRAF6)/PI3k/ AKT/NF-kB signaling pathway expression levels were measured in serum/WBC (buffy coat) by real-time
RT-PCR and normalized using $\Delta \Delta \mathrm{Ct}$ formula with U6B as a normalization control for the microRNAs and Glyceraldehyde-3-phosphate dehydrogenase (GAPDH) as an endogenous control for mRNAs. The $\Delta \Delta \mathrm{C}$ Baetge, $\mathrm{B}$ Lockard $\mathrm{Ct}$ formula, $\mathrm{Ct}$ represents the real time cycle number at which microRNA and mRNA probe fluorescence is exponential. Data were analyzed by MANOVA and presented as changes from baseline after $12 \mathrm{wks}$.

\section{Results}

An overall significant MANOVA interaction was observed among EX and C groups (Wilks' Lambda $\mathrm{p}<0.001$ ). MANOVA univariate analysis revealed no significant interactions among groups in changes in microRNA 146a (EX -0.73 \pm 2.0 ; C $-0.28 \pm 2.1, \mathrm{p}=0.46$ ); TRAF6 (EX $1.35 \pm 2.7 ; \mathrm{C}-0.74 \pm 3.5, \mathrm{p}=0.52)$; mRNA expression levels of PI3K (EX $-2.4 \pm 4.5$; C $-1.8 \pm 2.9, \mathrm{p}=0.66$ ); AKT (EX $-1.34 \pm 4.2$; C $-0.67 \pm 7.4, \mathrm{p}=0.70$ ); or, mRNA NF-kB (EX $-1.6 \pm 3.2 ; \mathrm{C}-0.73 \pm 3.2, \mathrm{p}=0.40)$. Significant interactions were observed among groups in changes in microRNA 21 (EX - $1.5 \pm 2.34$; C $0.13 \pm 2.2, \mathrm{p}=0.03$ ); mRNA expression level of its target gene PTEN (EX $-4.5 \pm 3.2$; C -1.6 $\pm 3.4, \mathrm{p}=0.005)$; mRNA IL-6 (EX $-2.8 \pm 3.6$; C 2.8 \pm 2.2 , $\mathrm{p}<0.001$ ); and, mRNA TNF $-\alpha$ expression levels (EX $-0.52 \pm 2.5 ; \mathrm{C} 2.3 \pm 1.9, \mathrm{p}<0.001)$. Exercise and dietinduced changes in mRNA IL- 6 and mRNA TNF- $\alpha$ expression were positively and significantly correlated to changes in body weight $(r=0.47, r=0.30)$, fat mass $(\mathrm{r}=0.48, \mathrm{r}=0.31)$, and percent body fat $(\mathrm{r}=0.48, \mathrm{r}=0.32)$, respectively. 


\section{Conclusion}

Results of this study indicate that exercise and dietinduced weight loss affects molecular changes in circulating microRNAs, significantly affects microRNA 21 and its target gene PTEN, mRNA TNF- $\alpha$, and mRNA IL-6 levels suggesting a anti-inflammatory response compared to a control group. These findings suggest that exercise and diet-induced weight loss is significantly associated with a reduction in inflammation. However, more research is needed to understand microRNA regulation associated with inflammation in response to exercise.

\section{Acknowledgements}

Supported by Curves International (Waco, TX).

\section{Authors' details}

'Exercise \& Sport Nutrition Lab, Department of Health and Kinesiology, Texas A\&M University, College Station, TX 77843, USA. ${ }^{2}$ Department of Nutrition and Food Science, Texas A\&M University, College Station, TX 77843, USA.

Published: 6 December 2013

doi:10.1186/1550-2783-10-S1-P24

Cite this article as: Simbo et al: Effects of exercise and diet-induced

weight loss on markers of inflammation II: impact on microRNA 21 and

microRNA 146a expression and their regulatory role. Journal of the

International Society of Sports Nutrition 2013 10(Suppl 1):P24.

Submit your next manuscript to BioMed Central and take full advantage of:

- Convenient online submission

- Thorough peer review

- No space constraints or color figure charges

- Immediate publication on acceptance

- Inclusion in PubMed, CAS, Scopus and Google Scholar

- Research which is freely available for redistribution

Submit your manuscript at www.biomedcentral.com/submit
C Biomed Central 